Elżbieta DACZKOWSKA-KOZON

\title{
PRELIMINARY SURVEYS ON THE LACTIC ACID BACTERIA OCCURENCE IN THE BALTIC SEA FISHES
}

\section{WSTĘPNE BADANIA NAD WYSTĘPOWANIEM BAKTERII FERMENTACJI MLEKOWEJ W RYBACH BALTYCKICH}

\author{
Department of Food Microbiology \\ Institute of Marine Food Technology, \\ Academy of Agriculture, Szczecin
}

\begin{abstract}
Qualitive and quantitative analysis proved lactic acid bacteria to be present in the alimentary tracks of the Baltic Sea fishes. Its numbers depended on feeding type and fishing period of the fish. Lactic acid bacteria were represented most numerously in the alimentary tracks of herrings, with the dominance of lact obacilli.
\end{abstract}

\section{INTRODUCTION}

Primarily treated as being indigenous to terrestrial environment, lactic acid bacteria were isolated, also, from marine environment far from populated areas (Schr $\phi$ der at al. 1980). Psychotrophic lactic acid bacteria of $L$. plantarum type were isolated from the alimentary tracks of some fish species caught in the North Atlantic, the Sea, the North Sea and the Baltic Sea as well as from krill (Thysanoessa sp.) from Norwegian fjord and from pacific cyster (Grassostrea gigas) Kraus, 1966; Preis and Lee, Schr $\phi$ der et al., 1980).

The aim of this work was to determine, wheather and to what extend Baltic Sea fishes harboured lactic acid bacteria.

\section{MATERIAL AND METHODS}

The subject of surveys were alimentary tracks of 64 fresh, Baltic Sea fishes, stored in ice, including:

33 herring (Clupea harengus L.) 
Lactic acid bacteria in the Baltic Sea fish

\begin{tabular}{|c|c|c|c|c|c|c|c|}
\hline \multirow{2}{*}{ Fish species } & \multirow{2}{*}{$\begin{array}{l}\text { No of } \\
\text { individuals }\end{array}$} & \multirow{2}{*}{$\begin{array}{l}\text { Fishing } \\
\text { period }\end{array}$} & \multicolumn{4}{|c|}{$\begin{array}{l}\text { CFU of lactic acid bacteria per } 1 \mathrm{~g} \text { of } \\
\text { alimentary track }\end{array}$} & \multirow{2}{*}{ Notice } \\
\hline & & & $<2$ & $2-99$ & $100-999$ & $>10^{3}$ & \\
\hline \multirow{4}{*}{$\begin{array}{l}\text { herring } \\
\text { (Clupea } \\
\text { harengus) }\end{array}$} & 10 & $01.88^{*}$ & - & 1 & 6 & 3 & \\
\hline & 10 & 06.87 & - & - & 8 & 3 & \\
\hline & 10 & 04.86 & - & 8 & 2 & - & spawning \\
\hline & 3 & 07.85 & - & - & 3 & - & \\
\hline \multirow{2}{*}{$\begin{array}{l}\text { cod } \\
\text { (Gadus morhua) }\end{array}$} & 7 & 11.86 & - & 7 & - & - & \\
\hline & 1 & 03.85 & 1 & - & - & - & spawning \\
\hline \multirow{3}{*}{$\begin{array}{l}\text { flounder } \\
\text { (Platichthys } \\
\text { flesus) }\end{array}$} & 7 & 12.87 & 3 & 4 & - & - & \\
\hline & 15 & 11.86 & 1 & 14 & - & - & \\
\hline & 1 & 06.85 & 1 & - & - & - & \\
\hline
\end{tabular}


Results of the confirmatory tests for strains isolated from alimentary tracks of the Baltic Sea fishes

\begin{tabular}{|c|c|c|c|c|c|c|c|c|c|c|}
\hline \multirow{4}{*}{$\begin{array}{l}\text { Fish } \\
\text { species }\end{array}$} & \multirow{4}{*}{$\begin{array}{l}\text { fishing } \\
\text { period }\end{array}$} & \multirow{4}{*}{$\begin{array}{l}\text { method of } \\
\text { estimation }\end{array}$} & \multirow{4}{*}{$\begin{array}{l}\text { No of } \\
\text { isolated } \\
\text { strains }\end{array}$} & \multirow{4}{*}{$\begin{array}{l}\text { No of } \\
\text { regrown } \\
\text { strains }\end{array}$} & \multirow{2}{*}{\multicolumn{2}{|c|}{ G+; katalase-; OF+ }} & \multirow{4}{*}{ others } & \multicolumn{3}{|c|}{ Percent $(\%)$ of } \\
\hline & & & & & & & & \multicolumn{2}{|c|}{$\mathrm{G}+, \mathrm{k}-, \mathrm{OF}+$} & \multirow{2}{*}{ others } \\
\hline & & & & & \multirow{2}{*}{ rods } & \multirow{2}{*}{ cocci } & & roods & cocci & \\
\hline & & & & & & & & in No of & regrown & strains \\
\hline \multirow{4}{*}{ herring } & 01.88 & \multirow{9}{*}{ immediate } & $-*$ & & & & & & & \\
\hline & 06.87 & & 40 & 21 & 18 & 3 & - & 86 & 14 & 0 \\
\hline & 04.86 & & 50 & 27 & 6 & 3 & 18 & 22 & 14 & 64 \\
\hline & 07.85 & & 54 & 40 & - & 3 & 37 & - & 8 & 92 \\
\hline \multirow{2}{*}{$\operatorname{cod}$} & 11.86 & & 45 & 43 & 39 & 2 & 2 & 90 & 5 & 5 \\
\hline & 03.85 & & 0 & - & - & - & - & - & - & - \\
\hline \multirow{3}{*}{ flounder } & 12.87 & & 30 & 28 & 8 & - & 20 & 29 & - & 72 \\
\hline & 11.86 & & 4 & 4 & 2 & 2 & - & 50 & 50 & 0 \\
\hline & 06.85 & & 7 & 6 & - & - & 6 & 0 & 0 & 100 \\
\hline \multirow{4}{*}{ herring } & 01.88 & \multirow{8}{*}{$\begin{array}{l}\text { after } 48 \mathrm{~h} \\
\text { of incubation } \\
\text { at } 20^{\circ} \mathrm{C} \\
\text { with } \\
1 \% \text { glucose }\end{array}$} & 52 & 50 & 46 & 4 & - & 92 & 8 & 0 \\
\hline & 06.87 & & 70 & 61 & 57 & 1 & 3 & 93 & 2 & 5 \\
\hline & 04.86 & & 48 & 22 & 17 & 1 & 4 & 77 & 5 & 18 \\
\hline & 07.85 & & 15 & 10 & - & 6 & 4 & 0 & 60 & 40 \\
\hline $\operatorname{cod}$ & 11.86 & & 30 & 15 & 15 & - & - & 100 & 0 & 0 \\
\hline \multirow{3}{*}{ flounder } & 12.87 & & 20 & 20 & 18 & 2 & - & 90 & 10 & 0 \\
\hline & 11.86 & & 15 & 5 & 1 & 4 & - & 20 & 80 & 0 \\
\hline & 06.85 & & $-*$ & & & & & & & \\
\hline
\end{tabular}


23 flounders (Platichthys flesus L.)

and 8 cods (Gadus morhua L.)

Microbiological analysis of samples was carried out within 24 to 48 hours after fish catching. Asseptically collected alimentary tracks were homogenized with $0,1 \%$ buffered peptone water $(1: 2)$ and than serially diluted.

In such prepared samples:

1. Total number of lactic acid bacteria was estimated. Material, from serial dilutions, transfered to Petri dishes was overlayed with MRS agar of pH 5,5 (2) and incubated at $20^{\circ} \mathrm{C}$ for $72 \mathrm{~h}$. Grown up colonies were counted and selected, at random, for identification. Counted numbers of colonies were corrected after the preliminary identification of isolated strains.

2. Qualitative analysis was carried out.

Enriched. by addition of $1 \%$ glucose, samples were incubated for $48 \mathrm{~h}$ at $20^{\circ} \mathrm{C}$ prior to spreading on the plates. After incubation, samples were treated as the ones above.

In both cases preliminary identification of isolated strains was carried out. G-positive, katalase-negative, fermenting glucose rods and cocci were considered as lactic acid bacteria (Sharrpe, 1979).

\section{RESULTS AND DISCUSSION}

Qualitative analysis of the alimentary tracks of the Baltic Sea fishes proved the number of lactic acid bacteria harboured there to be visibly different and dependant on the fish species and fishing period (Table 1).

Lactic acid bacteria were represented most numerously within the herring's alimentary tracks. Its numbers varied from $1,9 \times 10^{1}$, during spawning season, to $9.5 \times 10^{3} \mathrm{CFU}^{*} / \mathrm{g}$, when feeding intensively. At the same time number of lactic acid bacteria stated in the alimentary tracks of cods and flounders were much lower and ranged, respectively, from $<2$ to $3,8 \times 10^{1}$ and $<2$ to $4,5 \times 10^{1} \mathrm{CFU} / \mathrm{g}$.

Number of lactic acid bacteria in the alimentary tracks of 1 cod and 5 flounders, lower than the level detectable by the applied method, did not signify lack of these bacteria in that environment. Qualitative analysis of the same samples, enriched in $1 \%$ glucose, resulted, in all cases, in isolation of G-positive, katalase- negative, fermenting glucose rods and cocci (Table 2).

The lactic acid bacteria's growth stimulation, by enrichment of natural environment with carbohydrates, applied by $\operatorname{Sch} \phi$ der et al. (1980), let them isolate psychrotrophic bacteria of $L$. plantarum type from alimentary tracks of saithe (Pollachius virens) and krill from Norwegian fjords as well as from saithe and capelin (Mallotus villosus) from the North Atlantic and the Barents Sea (Schroder et al., 1980).

The most probable cause of sporadic isolation cases of lactic acid bacteria from marine fishes alimentary tracks could have been ussually low number of those bacteria in that 
environment; lower than the one, possible to be detected, by traditionally applied methods.

Herring sems to be the only exception to the above statement. Lactic acid bacteria were isolated from all the tested alimentary tracks of that, feeding on plancton, fish, no matter the isolation technic applied.

Variable due to fishing period, however, higher, than in the alimentary tracks of the other Baltic Sea fish species, numbers of lactic acid bacteria in herring, let, probably, Kraus, cited by Schr $\phi$ der et al. (1980), isolate psychrotrophic bacteria of L. plantarum type from the Baltic Sea herring.

Preliminaiy differentiation of isolated strains proved G-positive lactobacilli to dominate in most of the tested samples.

Among the strains isolated from MRS medium, with directly spreaded, diluted material, other, than lactic acid bacteria, stated for 0 to $100 \%$ of isolates (Table 2). Share of another type of microorganisms, isolated from the enriched samples, was lower and ranged from 0 to $40 \%$.

Low selectivity of the modified MRS medium, makes isolation of lactic acid hacteria from an environment, where being in minority, more difficult. Some authors also pointed out to an unsatisfactory selectivity of MRS medium, officially adviced for isolation of lactic acid bacteria (Hitchener et al., 1982, Kitchell and Shaw, 1975).

Variable nutritional and environmental requirements of lactic acid bacteria make all, so far, offered mediums for general purposes, not fully satisfactory. Commonly used MRS medium, beyond its rather low selectivity, enables growth of most representatives of that group, which is the case when presence of lactic acid bacteria is to be stated.

\section{CONCLUSSION}

1. Qualitative analysis of samples enriched with $1 \%$ glucose proved the G-positive, katalase-negative, fermenting sugar rods and cocci to be present in the alimentary tracks of all tested Baltic Sea fish species.

2. Number of lactic acid bacteria in the alimentary tracks of the Baltic Sea fishes depended on the feeding type and fishing period of the fish.

3. Lactic acid bacteria were respresented most numerously in the alimentary track of herring exceeding, during intensive feeding of fish $10^{3} \mathrm{CFU} / \mathrm{g}$.

4. Lactobacilli were dominant group among the strains of lactic acid bacteria isolated from the alimentary tracks of the Baltic Sea fishes.

\section{REFERENCES}

Hitchener B.J., Egan A.F., Rogers P.J., 1982: Characteristic of lactic acid bacteria isolated from vacuum-packaged beef. - J. Appl. Bact., 52: 31-37.

Kitchell A.G., Shaw B.G., 1975: Lactic acid bacteria in beverages and food. -ed. J.G.Carr, C.V. Cutting, G.C. Whiting, Academic Press, London: 209-220. 
Kraus H., 1966: Kurze Mitteilung über das varkommen von Lactobazillen auf frischen heringen. Arch. Lebensmittelhyg., 12(5): 101-102.

Lindgren S., Clevström G., 1978: Antibacterial activity of lactic acid bacteria. - Swedish J. agric. Res., . 8: 61-66.

Price R.J., Lee J.S., 1970: Inhibition of Pseudomonas species by hydrogen peroxide producing lactobacilli. - J. Milk Food Technol. 33: 13-18.

Schroder K., Clausen E., Sandberg A.M., Raa J., 1980: Psychrotrophic Lactobacillus plantarum from fish and its ability to produce antibiotic substances. - Advances in Fish Science and Technology, Academic Press, London: 480-483.

Sharpe M.E., 1979: Identification methods for microbiologists. - ed F.A. Skinner, D.W. Lovelock, Academic Press, London: 233-259.

Translated: Dr. E. Dảczkowska-Kozon

Received: 1988.07 .28

\title{
Elżbieta Daczkowska-Kozon
}

\section{WSTĘPNE BADANIA NAD WYSTEPPOWANIEM BAKTER II FERMENTACJI MLEKOWEJ W'RYBACH BAŁTYCKICH}

\section{STRESZCZENIE}

Przeprowadzone analizy ilościowe i jakościowe prób wykazały obecność bakterii fermentacji mlekowej w przewodach pokarmowych śledzi, dorszy i storni z Morza Bałtyckiego.

Liczba bakterii fermentacji mlekowej, stwierdzona w $1 \mathrm{~g}$ przewodu pokarmowego zależała od typu odżywiania się ryby i okresu jej połowu. Najliczniej G-dodatnie, katalazo-ujemne, fermentujące glukozę pałeczki i ziarniaki reprezentowane były w przewodach pokarmowych śledzi. Dominantę zaś, w większości prób, stanowiły pałeczki z rodzaju Lactobacillus.

\author{
Author's address: \\ Instytut Technologii Żywności \\ Pochodzenia Morskiego \\ ul. Kazimierza Królewicza 4 \\ 71-550 Szczecin, \\ Polska (Poland)
}

